\title{
Meeting the market in a dry environment
}

PETER HYSLOP

Farmer, Crownthorpe

Farm location: Crownthorpe, $35 \mathrm{~km}$ west of Hastings.

Area: 354 ha: 149 flat terrace, 205 easy rolling.

Climate:

Prevailing winds: Westerly.

Rainfall, annual rainfall of 800 $1000 \mathrm{~mm}$. The main rainfall months are May to August inclusive. The area is subject to intermittent and often prolonged dry spells.

Winters:

Are normally mild and on average, 3 months long.

Summary: $\quad$ The property experiences a climate typical of inland Hawke's Bay. There are no serious wind, frost or flooding hazards.

Soil types: $\quad$ Takapau silt loam, Matapiro sandy loam and Kidnappers silt loam.

Present uses: (a) Conventional sheep and bull beef. All ewes bought in.

(b) Technosystem used for bull beef.

(c) 7 ha grapes $14-18$ years old.

Stock numbers: 1450 ewes

340 R1 bulls

320 R2 bulls

\section{Outline of early lambing programme}

Targeting Marks and Spencer market.

\section{Reasons}

Climate: Avoiding climate extremes, e.g., summer dry.

Financial: Chilled market very strong pre-Christmas.

\section{Management factors}

Pre-tupp: Adlib feeding ewes from weaning to achieve $65 \mathrm{~kg}$ liveweight at tupping.

Tupping: Rams harnessed changing crayon colours for each cycle.

Scanning: For singles and twins.

Grazing: Ad lib all year except 6 weeks prior to lambing.

Shearing: Pre-lamb.
Lambing: Set stocked with ewes shedded out ASAP.

Drafting: Lambs drafted of ewes, ewes shedded out.

\section{Marks and Spencer criteria}

Go outside given parameters at your peril!

\section{How Marks and Spencer compliments other farming policies}

\section{Pluses}

Taking advantage of seasonal climate variation.

Culling ewes early.

Creation of space.

\section{Minuses}

Lambing \% decline.

Stocking rate reduction.

Delivery on time and in full.

\section{Results and analysis}

Lambing \%: $\quad$ Acceptable but not high.

$M \& S$ Results: Tight contract criteria result in an average qualifying percentage. Ranking against other growers is high.

\section{General}

Big difference between early and later lambing.

Work back from first day of killing.

Most emphasis placed on 12 weeks covering JulySeptember feeding period.

\section{Summary}

The climate is very conducive to an early lambing programme as our mild winters allow some grass growth resulting in good lamb growth rates. Marks and Spencer criteria are tight, so strict drafting procedures are essential. Only a high qualifying percentage will result in high per head dollar values. Early sale of Marks and Spencer lambs is complimentary to other farming operations and allows greater flexibility with seasonal extremes. The early lambing operation is geared basically 
for 12 weeks of production from the time when lambs hit the ground to their sale. If the majority of early-born singles do not meet the contract, then the whole procedure is a waste of time and resources. 